\title{
T-Cell Surface Glycoprotein CD3 Zeta
} Chain

National Cancer Institute

\section{Source}

National Cancer Institute. T-Cell Surface Glycoprotein CD3 Zeta Chain. NCI Thesaurus. Code C38903.

T-cell surface glycoprotein CD3 zeta chain (164 aa, $18 \mathrm{kDa}$ ) is encoded by the human CD247 gene. This protein is involved in T-cell intracellular signaling. 